\title{
European Identity between Religiousness and Secularity
}

\author{
Galina S. Klimova \\ The Russian Presidential Academy of National Economy and Public Administration \\ 84, Prospekt Vernadskogo, Moscow, 119571, Russian Federation \\ klimova-gs@ranepa.ru
}

\begin{abstract}
The role of religion in the structure of European identity was not on the top of agenda before the discussion of the Constitution project, but in the light of the intensive migration and Brexit this question appears to be more and more important. The issue of the interconnection between religion and European identity has several dimensions: the role of believing and belonging as well as Christianity and it forms in construction and functioning of European identity and feeling of Europeanness. The correlation analysis of Eurobarometer data (2009-2019), European Value Study $\left(2^{\mathrm{d}}\right.$ and $3^{\mathrm{d}}$ waves) and World Value Survey $\left(1^{\text {st }}-6^{\text {th }}\right.$ waves$)$ data allows us to prove that, being secular in its roots, European identity has intense ties with religiousness. Religion appears to be a factor of European identity not within any confession, but more as a faith. Nevertheless, correlation analysis also demonstrates differences in the influence of Christian confessions on the one's self-identification as European, which allows to look wider at the religion function in European Identity and claimed European values (mainly of secular and Enlightenment origin) in historical retrospective. This means that religion perspective not only reopens the discussion of the substance of being European, but also is one of key approaches to the urgent issues of peaceful group coexistence within European Union.
\end{abstract}

Keywords: European identity, religiousness, denomination, European integration, European Union, Christianity

Article history: Submitted on 30.07.2020. Accepted on 10.08.2020.

For citation: Klimova G.S. European Identity between Religiousness and Secularity. RUDN Journal of Political Science. 2020; 22 (4): 617-633. DOI: 10.22363/2313-1438-2020-22-4-617-633

\section{Европейская идентичность между религиозностью и секулярностью}

\author{
Г.С. Климова \\ Российская академия народного хозяйства и государственной службы \\ при Президенте Российской Федерации \\ Российская Федераџия, 119571, Москва, Проспект Вернадского, 84 \\ klimova-gs@ ranepa.ru
}

Аннотация. Роль религии в структуре европейской идентичности не была на повестке дня до обсуждения проекта Конституции, но в свете интенсивной миграции и Brexit этот

C) Klimova G.S., 2020

This work is licensed under a Creative Commons Attribution 4.0 International License https://creativecommons.org/licenses/by/4.0/ 
вопрос представляется все более и более важным. Взаимосвязь между религией и европейской идентичностью имеет несколько измерений: роль веры, а также христианства и его ветвей в построении и функционировании европейской идентичности и чувства европейскости. Корреляционный анализ данных Евробарометра (2009-2019), European Value Study (2 и 3 волны) и World Value Survey (1-6 волны) позволяет доказать, что, будучи секулярной по своей природе, европейская идентичность имеет тесные связи с религиозностью. Религия представляется фактором европейской идентичности не в рамках какой-либо конфессии, а скорее как вера. Тем не менее корреляционный анализ также демонстрирует различия во влиянии христианских конфессий на самоидентификацию человека как европейца, что позволяет взглянуть шире на функцию религии в европейской идентичности и декларируемых европейских ценностях (в основном светского и просветительского происхождения) в исторической ретроспективе. Религиозная перспектива не только открывает дискуссию о сущности европейской идентичности, но также является одним из ключевых подходов к проблеме мирного сосуществования групп в рамках Европейского союза.

Ключевые слова: Европейская идентичность, религиозность, конфессия, европейская интеграция, Европейский союз, христианство

История статьи: Поступила в редакцию 30.07.2020. Принята к публикации 10.08.2020.

Для цитирования: Klimova G.S. European Identity between Religiousness and Secularity // Becтник Российского университета дружбы народов. Серия: Политология. 2020. Т. 22. № 4. 617-633. DOI: 10.22363/2313-1438-2020-22-4-617-633

\section{Introduction}

What does it mean to be European today? Does it mean to be democrat, Christian or citizen of the European Union? The borders of Europe are vague as well as the idea of Europe itself, which means that Europeans combine vast variety of language, political, ethnic and other identities. The official motto of the EU "In varietate Concordia" (Unity in diversity) perfectly reflects not only the political, economic and social, but also the extreme ethno-confessional diversity of the EU people. The population of the EU-28 is above 513.5 million inhabitants belonging to more than 80 ethnic groups ${ }^{1}$. At the same time, these people speak 24 official languages of the EU, more than 60 languages of ethnic minorities, not to mention more than a hundred migrant languages ${ }^{2}$. Religious and confessional variety of Europe is also significant and complicated. Anne Norton subtly worded this complexity, noted that in addition to Christian, "There is a pagan Europe, still alive in North and South. There is a secular Europe, an atheist Europe. There is a Jewish Europe and a Muslim Europe. These are not separate, but strands woven together, a tapestry bearing the colors of one vividly in one quarter, while another shines in the next" [1, p. 141-142].

Obviously, such a plexus of the worldviews has great impact and ambivalent potential within the development of the EU. But it is worth noting that before the

\footnotetext{
${ }^{1}$ Population and population change statistics. Eurostat data. [updated 2020 Jun 10; cited 2020 Jun 20]. URL: http://ec.europa.eu/eurostat/statistics-explained/index.php/Population_and_population_change_statistics (Data are given by $10^{\text {th }}$ of June, 2020. The United Kingdom left the EU from 1 February 2020. The data used in this paper cover the EU-28).

${ }^{2}$ EU languages. Eurostat data. [updated 2019 Dec.; cited 2020 May 11]. URL: https://europa.eu/ european-union/about-eu/eu-languages_en
} 
discussion over the EU Constitution in 2004, the role of religion and, first of all Christianity, in the integration process was not a part of wide public discourse ${ }^{3}$. However, the hypothetical mention of Christianity contribution to the development of the European community in the preamble of the EU Constitution has provoked a lively polemic that has not subsided since then. The discussion on the European religious heritage demonstrated one of the numerous division lines between member states: Scandinavian countries and France insisted on the principle of laicism, while Spain, Italy, Poland and Ireland protested against the atheist image of the EU. There was also no unity within the member states. Opponents of any reference to the Christian heritage in the Constitution text pointed to the principle of church and state separation enshrined in many national constitutions. They expressed the fear of turning the EU into a kind of Christian club. Whereas supporters noted the importance of preserving the historical memory of the religion role in the development of Europe. The controversy about the preamble grew into a discussion of more general issues of the religious discourse "return into" public space and the function of religion in modern Europe and European supranational identity.

Despite all the differences in the principles governing the church and state relation (for example, France is one of the most rigid of the laicist systems, whereas the Evangelical Lutheran Church is the official state church in Denmark), modern Europe is the area of secularism. Legally it is ensured by the fact that the constitutions of all EU member states as well as supranational legal acts guarantee freedom of conscience. Article 9 of the European Convention on Human Rights establishes the right to freedom of religion ${ }^{4}$. Freedom of conscience is also guaranteed by Article 10 of the Charter of Fundamental Rights of the European Union ${ }^{5}$. Thus, Article 10 of the Charter reflects Article 9 of the Convention and should be interpreted correspondingly. The Charter of Fundamental Rights became law in 2009 when the Lisbon Treaty commenced. Also, Article 17 of the Treaty on the Functioning of the EU (2009) included the provisions of the Declaration No. 11 (Amsterdam Treaty) on the status of the church and non-denominational organisations. According to paragraph 1 of this article, "The Union respects and does not prejudice the status under national law of churches and religious associations or communities in the Member States" . Paragraph 3 of Art. 17 points out that "Recognising their identity and their specific contribution, the Union shall maintain an open, transparent and regular dialogue with these churches and

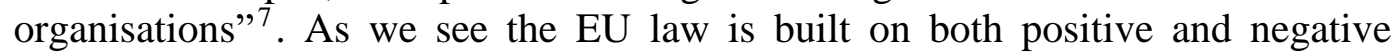

\footnotetext{
${ }^{3}$ Despite of number and significance of academic publications (see, for example, [2-5] in EU political and public sphere this problem was not widely discussed till 2004. It appeared to be more intense because of the debate on the accession of Turkey to the European Union in the mid-2000s.

${ }^{4}$ European Convention on Human Rights. [cited 2020 May 20]. URL: https://www.echr.coe.int/ Documents/Convention_ENG.pdf

${ }^{5}$ Charter of Fundamental Rights of the European Union. [cited 2020 May 20]. URL: https://eur-lex.europa.eu/legal-content/EN/TXT/?uri=CELEX:12012P/TXT

${ }^{6}$ Consolidated version of the Treaty on the Functioning of the European Union. [cited 2020 May 20]. URL: https://eur-lex.europa.eu/resource.html?uri=cellar:41f89a28-1fc6-4c92-b1c8-03327d1b1ecc. 0007.02/DOC_1\&format=PDF

${ }^{7}$ Ibid.
} 
dimensions of religious freedom, it guarantees the right to believe and practice religion, as well as the right not to believe. Supporting religious diversity and the inadmissibility of discrimination on the basis of denomination (Article 22 and Article 21 of the Charter of Fundamental Rights), the EU is built on a secular understanding of freedom of conscience. Religion is seen as a private affair of every person, which should be eliminated from the public sphere.

The simplest conclusion could be a statement about a secular nature not only of the legal but also the political and social landscape of EU. But is it true? Events of the XXI century (the ban on wearing hijabs in schools, attacks related to the publication of Prophet Muhammad's cartoons, the polemic about the demonstration of the crucifixion in educational institutions, sentences for an attack against religious feelings, etc.) suggest that religion is presented in the public sphere and have called into question secularity of EU. European Union cannot be studied as a secular system and should be revised in terms of postsecularism, which gives the new research optics of the complex problems of European studies. In this context, this paper focuses on the issue of the role of religious factor in the structure of European identity. Religious factor includes two aspects: confession and believing. Therefore, the working hypothesis is that European identity has secular roots but has intense ties with the religiosity which strengthen it, paradoxically, beyond the confessional boundaries.

The paper proceeds by a short methodological comment that defines author's theoretical position and describes research data. Then it observes the position of religion in values that are claimed to be the fundamental of the European Union. The paper examines the religious demographics of EU and specify exception of European religious tradition. Relying on the idea that Europeans are mainly religious people on the "believing without belonging" basement, the paper continues looking at the role of religiosity in European identity. It then focuses on the position of Christianity in EU process and compares the effect of its branches on the sense of Europeanness. Each part of the paper includes qualitative and quantitively analysis of survey data that show the presence of religion in secular European identity.

\section{Methodological commentary}

Before proceeding to the main part, I would like to note several aspects that outline the methodological field of the research. To begin with, it is necessary to distinguish the category of European identity. Having the political origin ${ }^{8}$ this concept is an indispensable and stable language construct of European studies. However, the variety of epistemic and functional utilization of the concept [See, 6]

\footnotetext{
${ }^{8}$ The official appearance of "European identity" in the public discourse is due to the Copenhagen Declaration of 1973. By the mid-1970s, during the turbulent debate around the Tindemans report, "European identity" became part of the official discourse of the European Community. Throughout the 1980s and early 1990s the frequency of document use of the concept only increased. By the time of the foundation of the European Union, "European identity" has become one of the key components of socio-political and scientific integration discourses.
} 
requires the clarification of the author's understanding. European supranational identity is regarded in the framework of the constructivist approach, i.e., as a result of the "construction" of a certain image from significant symbols that can become the basis for the consolidation of EU citizens. Such symbols can be either political and legal or cultural and historical. For example, European citizenship and the rights of EU citizens can be based on civil (political) identity, whereas a common history (for example, antiquity) and a common culture (for example, Christianity) can constitute a cultural one. In other words, European identity is seen as formation discoursive [7] - a way not only to reflect the world, but also to design it. This paper is an attempt to examine the limits of reconcilability of cultural and civil identities.

The use of the concepts of secularism and postsecularism in this paper also need to be specified. Until recently secularization was regarded as the loss of the religion its social significance and as an integral component of modernity: the more modern is the society the less religious it is. One of the key authors of the secularization theory P. Berger framed a term as «the process by which sectors of society and culture are removed from the domination of religious institutions and symbols» $[8$, p. 107]. But the processes of last decades have raised the question if the world has ever been secular. As a result, the wave of disputes about the nature of «religious» and «secular» led to the perception of the limitation of the dichotomy. Thus $\mathrm{J}$. Habermas underlined the collision of the reality and the European persuasion that religion plays an exclusively marginal role in the modern world $[9,10]$. While J. Casanova suggested that over among three key meanings of the secularization concept -1 . religion loss of its social significance; 2 . privatization of religion and 3. differentiation of the secular spheres, only third is still actual nowadays [11]. For his part, T. Asad precisely noted that if religion became a part of politics it could no longer be indifferent to social debates [12]. The list of revisionists, of course, is not limited by these authors (See [13]). But all these publications showed that the concept of secularization is limited to grasp the new pluralistic reality of the world and stepped forward to epistemic abilities of postsecularism.

Religion is obviously not a marginal aspect of contemporary social communication and development. Majority of the world conflicts are described in terms of religion, churches and non-denominational organizations act as interpretative communities, visible presence of different, often "other", confessions and etc. are the brightest signs of this trend, which cannot be analyzed just within secularism. But not only analytic limits of secular theory made the concept of postsecularism popular in academic sphere. The practical requirement of citizens equality regardless their worldview and the foundation of modern society on the consent of all its members is maybe not more likely to be reached on the postsecular basis, but at least it is the step for better understanding the possibility of a durable peaceful coexistence of various religious and non-religious groups within one society. But it is important to underline that postsecular paradigm is not just the claim of the religion return into public sphere or the era of "new Middle Ages". In his latest book D. Uzlaner describes postsecular theory in terms of habermasian and non-habermasian approaches. If J. Habermas claimed that religion is experiences 
the process of self-modernisation, majority of non-habermasian interpretations regard postsecularity not only as a rejection of the anti-religious prejudices of the secular modern, but as a rethinking of the secularism itself, up to the possibility of going beyond the secular modernity to some alternative versions of it $[14$, p. $121-$ 124]. Admitting that any variant of postsecular paradigm could be perspective optic to study the European identity, We mainly base the study on the habermasian one as it allows to take into consideration pluralistic and discursive nature of the European identity and do not eliminate liberal aspect of it.

Relying on the postsecularism and being of the opinion that religion is an important factor in modern Europe, the aim is to observe the correlation between religiosity and confession on one hand and comprehension as European on the other hand. European identity can be defined by the question index of belonging to Europe and feeling as EU citizen (the latter as European identity is mainly a part of integration discourse). Also, We suppose that ties between religious factor and attitude to democracy can be used as an indicator of interrelation of religion and Europeanness. Whereas democracy is a stable element of European identity according to Eurobarometer ${ }^{9}$ and is claimed as a basic value of European Union.

Unfortunately, there are no reliable, up-to date data on religious denomination in many European countries. In addition, the statistics relating to religion sometimes contradict one another due to the method of the survey (questions about religiosity and denomination could be raised subjectively and objectively). Therefore, the research is based on data of World Value Survey, European Value Study and Eurobarometer. The survey methods as well as a sample do not allow to correlate data but guarantee more factored conclusions.

We consider risk of the ecological fallacy and understand that the link existing at the level of society can change the sign to the opposite one at an individual level [15]. But there is a strong cluster around the average meanings within the social units that form a common collective identity for their populations. This means that the social characteristics of individuals within the country are limited to certain borders and in spite of the unusual cases the majority of the population is grouped within the limited framework of the term "median citizen". That is why the paper is based on both aggregated for EU and individual countries data. Furthermore, it is obvious that in such abstract categories as religiosity and identity it is not a question of "hard ties".

\section{Religion in system of EU values}

If European identity is regarded as a formation discoursive it is clear that values associated with it play the key role in its functioning. According to the special report of Eurobarometer, $41 \%$ of Europeans believe that a single European currency is the most important element in the formation of the European identity. $40 \%$ choose democratic values as such a component. History and culture as significant symbols in the structure of European identity are noted by $26 \%$ of respondents. At the same

\footnotetext{
${ }^{9}$ See: Standard Eurobarometer 71. Spring 2009. Future of Europe; Standard Eurobarometer 77-92 European Citizenship.
} 
time, the unity of history is mainly associated with the overcoming of the Second World War experience, and only 9\% of respondents associate culture with religion ${ }^{10}$.

Similar picture is given by the analysis of regular Eurobarometer surveys of the EU citizens' individual values and the factors that create a sense of community and "Europeanness". Data study over the past 10 years confirms that citizens associate the European Union primarily with peace, human rights and democracy. On average, no more than $3 \%$ of respondents note religion as a significant symbol of the EU (See Fig. 1).

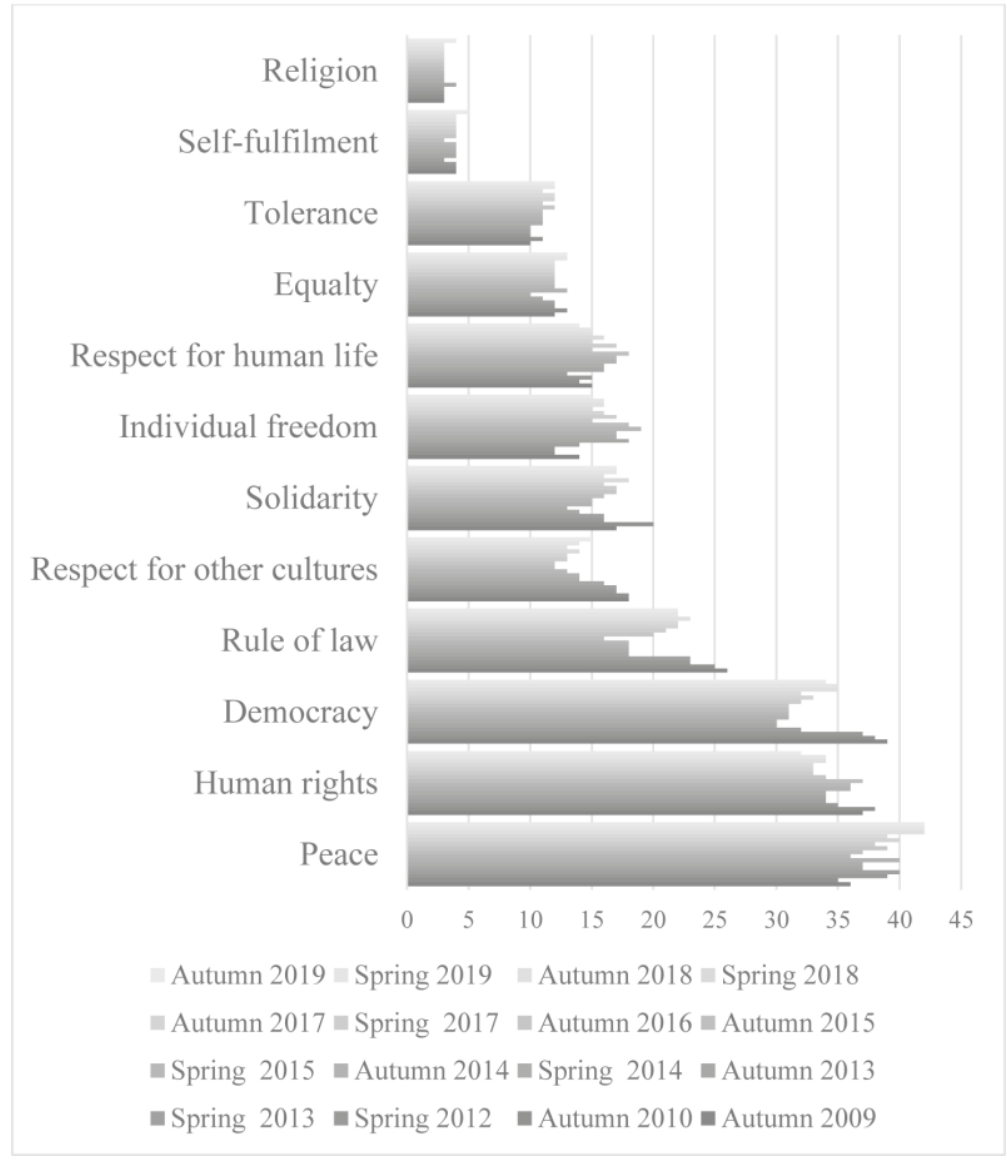

Fig. 1

The image of the EU

Source: Standard Eurobarometer 72-92 (2009-2019). URL: https://ec.europa.eu/commfrontoffice/ publicopinion/index.cfm/Survey/index\#p=1\&instruments=STANDARD (accessed: 20.06. 2020).

The feeling of the community of Europeans is associated with many factors, but culture, economics, history and values are often regarded as significant

\footnotetext{
${ }^{10}$ Special Eurobarometer 278. European cultural values. 2007. [updated 2019 Dec; cited 2020 Jun 20]. URL: https://ec.europa.eu/commfrontoffice/publicopinion/index.cfm/Survey/getSurveyDetail/instruments/SPECIAL/surveyKy/477/p/5
} 
symbols. Religion is included in the circle, but invariably remains in the last place. Only $8-11 \%$ of the respondents mark it as a determining factor in the community in last 8 years (See Fig. 2). The highest percentage of that answer among respondents was in $2007-13 \%$, which was more representative than rule of law or healthcare and reviles a secular tendency in EU values. Of course, it is not that straight, European culture (the chart below showing the long-term trend reveals that "culture" has topped the list of items) is strongly connected with religious heritage. But it is clear that the EU community is not mainly convinced in the categories of religion in public sphere.

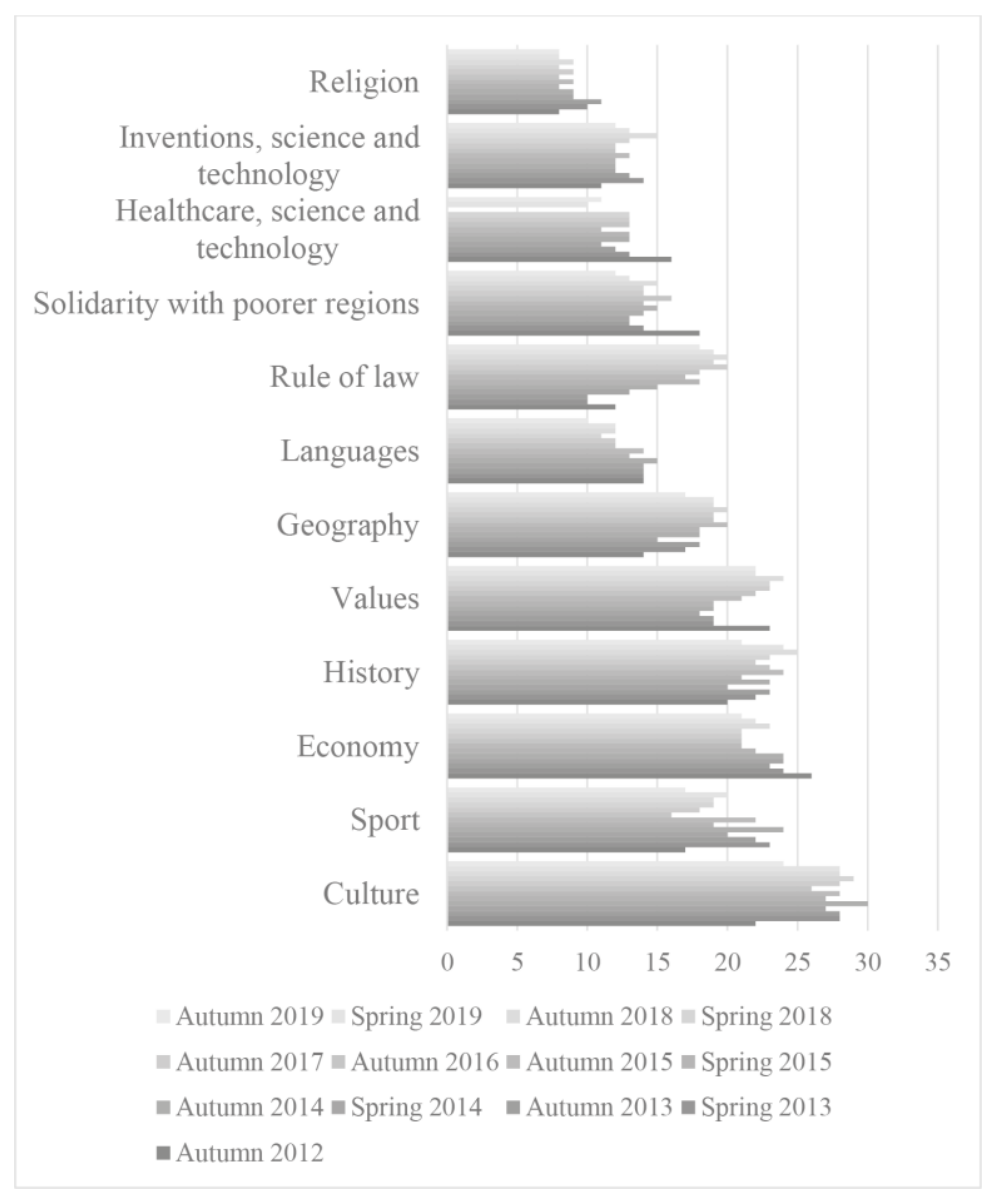

Fig. 2

A sense of community of EU citizens

Source: Standard Eurobarometer 78-92 (2012-2019). URL: https://ec.europa.eu/commfrontoffice/ publicopinion/index.cfm/Survey/index\#p=1\&instruments=STANDARD) (accessed: 21.06 .2020 ).

Personal values of Europeans also do not give religion the first place in the list (5-6\%), while peace, human rights, individual freedom seems to be more important for them (See Fig. 3). 


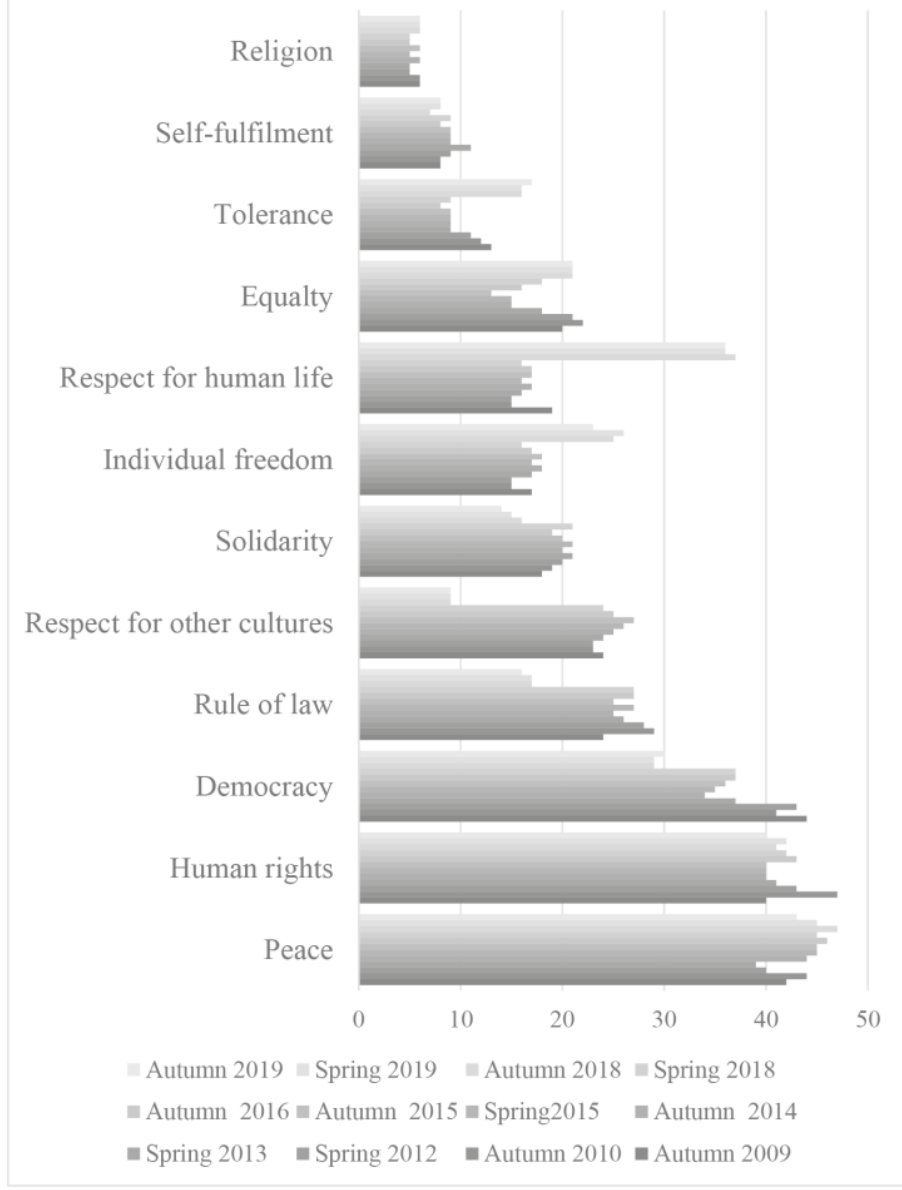

Fig. 3

The personal values of EU citizens

Source: Standard Eurobarometer 72-92 (2009-2019). URL: https://ec.europa.eu/commfrontoffice/ publicopinion/index.cfm/Survey/index\#p=1\&instruments=STANDARD (accessed: 20.06.2020).

Analysis of survey data faces obvious problems. First is that respondents do not always understand the concepts in the same way. Results of the Eurobarometer qualitative study demonstrate significant difference in the perception of the survey terms. Democracy, human rights, culture and etc. are regarded with meaningful variety. It is also true about religion. The second problem is that the list of Eurobarometer values and associations is proposed by sociologists, so people are limited in their choice.

Consequently, data of qualitive survey are an important way of doublechecking. According to 2014 aggregate report "Europeans and EU" participants most frequently mentioned values related to unity and solidarity, democracy and freedom, multiculturalism and tolerance as representing the EU. Religion was not even mentioned as a significant value of EU. While heritage and history, protection and promotion of culture were proposed by respondents. 
Revising the Eurobarometer results focus group participants were generally in agreement with them ${ }^{11}$. But some of them felt that the values identified in the quantitative survey seemed quite superficial and were not backed by any concrete action. This remark is important in case of the evaluation of the religion in system of EU values. Religion is not regarded as public political action by majority of respondents, at least on EU level.

Surveys consistently demonstrate the secular nature of the European consciousness. Religion is seen as part of public discourse by a minority of the EU population. However, religious affiliation and self-identification are not grounds for stigmatization. Only 2-3\% of the EU population faced discrimination on the basis of denomination, while sex and age are more frequent causes of infringement ${ }^{12}$. It is largely due to the secular tradition of modern European society that religious denomination is generally viewed as a private matter.

Religion is definitely a part of EU and EU citizens values, it is even in the list of the items providing sense of community in European Union. But it is always on the last place in these lists and not mentioned by qualitative Eurobarometer respondents. Still we are not sure what do they mean under culture as EU value the heritage of Enlightenment, Christian philosophy or pure art. Thus, one can claim that the European identity includes the idea of religious denomination as private matter. And in this sense can be considered as secular. Thus, Europe is not a land of atheism and religion plays a meaningful and complex role in European identity functioning.

\section{Religiousness and the sense of Europeanness}

The European scenery is dominated by numerous Christian churches, $80 \%$ of the museum content is connected with the Christian heritage. We may say that since early Middle Ages Europe was self-presented and regarded as a land of Christ. But it is obvious that the religious diversity of European continent is a part of its past and present. According to Eurobarometer majority of EU population belong to appropriate denomination (See Fig. 4). Only about 20-27 \% (atheists and agnostics) do not identify themselves as members of any church.

Data of World Values Survey and European Value Study give even more diverse picture - Europeans belong up to 17 denominations ${ }^{13}$.

\footnotetext{
${ }^{11}$ See: Eurobarometer Qualitative Study. The Promise of EU. Aggregate Report. 2014. [updated 2014 Sep; cited 2020 Jun 25]. URL: https://ec.europa.eu/commfrontoffice/publicopinion/archives/quali/q1_6437_en.pdf

${ }^{12}$ See: Special Eurobarometer 393. Discrimination in the EU. 2012; Special Eurobarometer 493. Discrimination in the EU. 2019. [cited 2020 Jun 25]. URL: https://ec.europa.eu/commfrontoffice/publicopinion/index.cfm/Survey/index\#p=1\&instruments=SPECIAL While the proportion of respondents who think that discrimination on the base of religion or belief is widespread is $47 \%$ and not $-48 \%$ in 2019.

${ }^{13}$ Unfortunately, the data of the waves do not cover all 28 -EU and due to this is not statistically representative but show the variability of EU religious denomination.
} 


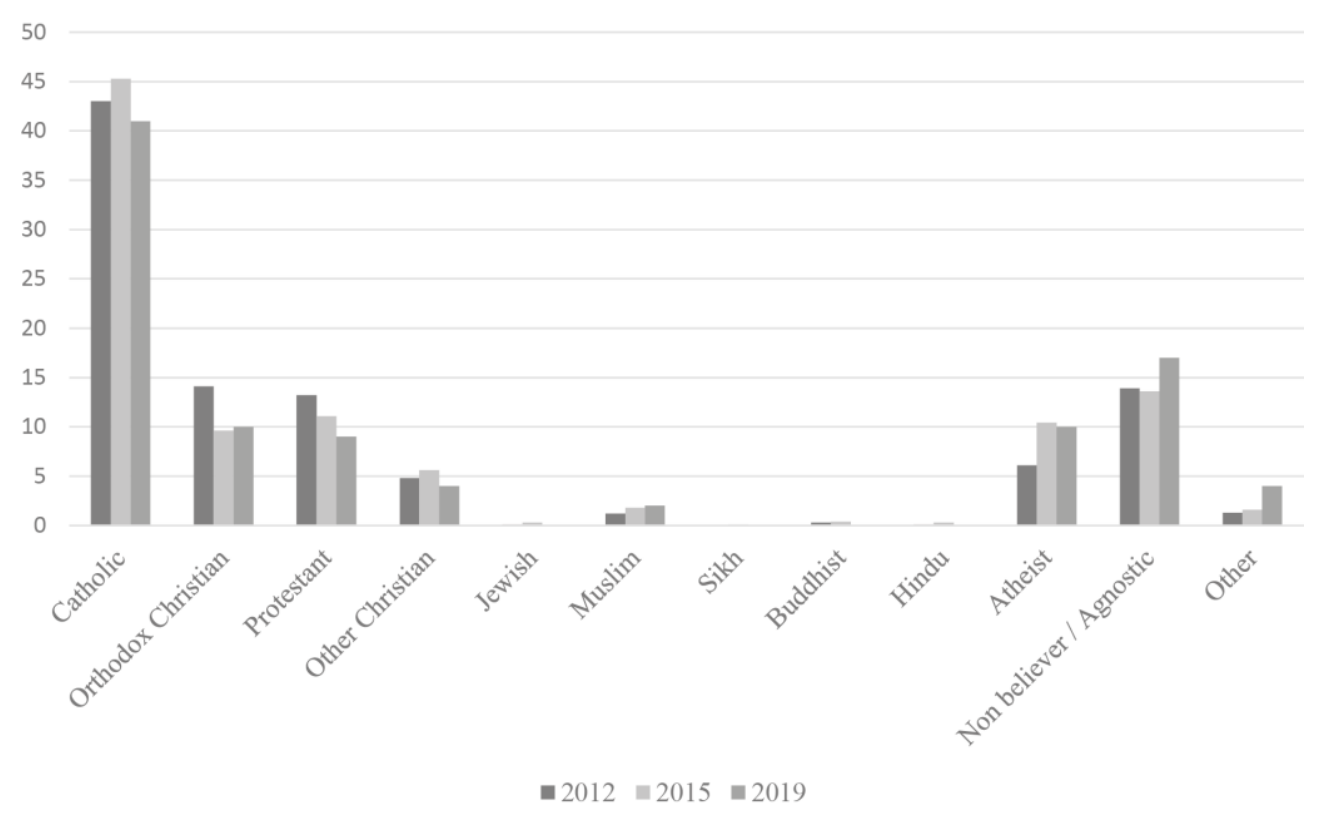

Fig. 4

Religious denomination ${ }^{14}$

Source: Eurobarometer (Special EB 393, 437, 493) via GESIS. URL: https://zacat.gesis.org/webview/ (accessed: 15.06.2020).

It is important to remember that the survey answer "not a religious person" does not signify absence of religion. Statistical data do not allow to distinguish if "not religious" means "non-religious believers" or the "non-religious unbelievers". The border between religious and non-religious is not that obvious. As Jean-Paul Willaume wrote, people who identify themselves "as religious are less clearly believing than before, while people who identify as 'non-religious' are less atheist than before" [16, p. 775]. So, even agnosticism and atheism can be regarded as a kind of denomination chosen in dialogue with the idea of religion.

Nevertheless, religious denomination does not mean that it necessarily effects everyday life. An increasing majority of Europeans has not been participating in religious practices on regular basis ${ }^{15}$, while maintaining relatively high level of private religiousness. $49,8 \%$ of EU population say that they believe in God and $29,6 \%$ believe in sort of spirit or a life force and only $17 \%$ do not believe in anything supernatural ${ }^{16}$. To a certain extent I can agree with Jose Casanova who noted that,

${ }^{14}$ Data are slightly different, which can be mainly explained as statistical discrepancy of the survey. Although rises and falls of appropriate groups are worth looking at with special attention.

${ }^{15}$ According to EVS Longitudinal Data $29 \%$ never or practically never attend religious services, $17,5 \%$ attend them on special holy days, $5,5 \%$ - more than once a week, $15,7 \%$ - once a week and $10,5 \%$ once a month.

${ }^{16}$ Special EB 437 via GESIS. EVS Longitudinal Data represent even higher level of religiousness: $63,6 \%$ - religious person, $25,4 \%$ - not a religious person, $4,7 \%$ - a convinced atheist. [updated 2019 Dec; cited 2020 Jun 15]. URL: https://zacat.gesis.org/webview/ Data of WVS vary from 54 to 
it is possible to talk of the "unchurching" of the European population and of religious individualization [17]. Citizens of EU believe without belonging and definitely have secular lifestyle ${ }^{17}$. Such plexus of religiousness and secular routine can be described by the concept of vicarious religion, proposed by Grace Davie [18, 19, p. 17-18]. By vicarious she meant the type of religion that is performed by an active minority but on behalf of majority of population. More important is that this inactive majority more than understand, but fully approve the minority's religious practice. These active churchgoers and first of all church leaders believe on behalf of others, giving them the sense of involvement.

European variety of denomination, complicated ties between religiousness and secular rationality provides the complexity and heterogeneity of the religious worldviews in Europe. EU is definitely a secular place in comparison with the other world, but it does not mean absence of religion. It means that European identity has strong ties with religiousness and Christian denomination but not because of obligation. Religion presence in European identity can be explained, on one hand, by European cultural heritage that has deep roots in confessional worldview, on the other, by modern consumption of choice. If in previous epochs denomination was either inherited or imposed, today it is the deal of personal choice. Looking for the answers, experience and emotions in religiousness of different origin can be explained in terms of Inglehart's theory of postmaterial consumption [20].

Remarkable that religiousness has rather controversial cohesion with the sense of Europeanness. EVS country data ${ }^{18}$ demonstrate rather weak inversive link between being a religious person and belonging to Europe $(r=-0,2)$, while convinced atheists are more likely to belong primarily to Europe $(r=0,3)$. We may suppose that people who regard themselves as religious feel more attached to their regional religious community and feel less cosmopolitan. But the confidence in EU tends to decline with sense of religiousness, religious people are more optimistic about EU $(\mathrm{r}=0,3)$, while the more atheistic is the person the more doubtful he is about EU $(\mathrm{r}=-0,3)$. Obviously, data give us only proportions of population and such coefficients are not the proof, they just can show existence of some connection between European identity and religion.

Data of WVS do not cover EU28 and in that case are less reliable. Nevertheless, different samples of WVS waves allow to extrapolate some conclusions to European Union. According to the data of two last waves of WVS the more religious are people the more they feel themselves citizens of EU $(r=0,7)$. Therewith the proportion of atheists increases number of those who do not feel as EU citizens $(r=0,7)$. Religious people tend to regard themselves not as Europeans but the citizens of EU.

$58 \%$ of religious people and from 7 to $8 \%$ of convinced atheists. [updated 2020 May; cited 2020 Jun 15]. URL: http://www.worldvaluessurvey.org/WVSOnline.jsp

${ }^{17}$ Obvious exception one can see in the the continuing requests for some sort of religious ritual at the time of a birth, a marriage, and, most of all, a death.

${ }^{18}$ Calculation is based on valid percentage. 
Comparison of EVS and WVS data proves the distinction between belonging to Europe and feeling EU citizen. The divergence of the idea of Europe and EU is clear, but both senses could be a part of European identity (cultural or civil). That is why the soft ties that the correlation and comparison demonstrate seems to be worth considering. Links between atheism and Europe, on one hand, and religiousness and EU, on the other hand, suggest the sacral nature of EU. The community over the continent is a beautiful idea with deep roots in the epoch of Enlightenment, but it is also a faith. EU take the moral high ground that push it to the complex relationship with religion, while religious people appear to be more supportive to the idea of EU unity. Vicarious religion happens to be a stable platform for supporting EU without taking part in its functioning.

\section{Christianity and European Union}

Increasing religious diversity and "believing without belonging" practice in modern Europe pose several questions. Is it fundamentally Christian place? and Is Christianity an inseparable part of European identity because of its historical and spiritual role and etc.? Practically one cannot ignore the relevance of Christian monuments, fests and sites in European cultural heritage.

But as any religion Christianity is not homogeneous. It has three major branches - Catholic, Orthodox and Protestant (not considering great variety of subdivision). The Weberian position that religious traditions influence the society has strong support among sociologists. In particular, the point is that each denomination is a basement for a variant of political culture [See, e.g. 21]. Thus, Protestant tradition of the church decentralization is presented as a reason that the Protestant countries are rather liberal and democratic. While Orthodox Christianity is sometimes regarded as "much less likely to develop stable democratic political systems" [22, p. 29-30] ${ }^{19}$.

Differences in the political cultures of the branches of Christianity have definitely influenced the approach to the European integration within these denominations. Brent F. Nelsen and James L. Guth contend that Catholic promotion of the unity of Christendom and its transnational structure have made it supportive of EU, while Protestant fear of Catholic dominance have caused Euroscepticism of the Protestant countries. They compare the Catholic view of Europe as a single cultural entity which should be formally established as a federation against Protestant preference for pragmatic cooperation over the sacrifice of sovereignty [23]. This deep cultural divide, rooted in the struggles of the Reformation, resists the ongoing secularisation and postsecularisation of the continent ${ }^{20}$.

\footnotetext{
${ }^{19}$ Somehow it is true that Romania, Bulgaria, Serbia, Macedonia, Russia, Greece and Cyprus, the Orthodox countries, could all be characterized by weaker institutions than those of northwestern Europe. This is partly because Orthodoxy has created its own alternative order. But not all academics share this idea.

${ }^{20}$ The Brexit case being mainly social and demographic is worth conceptualization through the lenses of denomination.
} 
Officially Orthodox Christianity was apart from integration process. Till XXI century Greece was the only Orthodox member-state. If the Roman Catholic Church has been playing an active role in the process of European unification, with the Vatican pro integration position and Protestant Churches also have not been staying aside, Orthodox churches since there liberation from Communist authorities have viewed the EU as an alien project [24]. Nowadays due to the ecumenism they play much more active role in EU. But even if we disregard the idea that Orthodox has cultural connections with weak democratic and civil institutions, we have to admit that the estrangement of Eastern European countries (mainly Orthodox) from the Western ones is more obvious than the difference between Catholic and Protestant member-states ${ }^{21}$.

Aggregated national data let us suggest that Christian denomination influences not only the support for integration, but somehow the sense of European identity. Thus, Brent F. Nelsen and James L. Guth counted that a 2004 EB shows visible correlation $(r=0,42)$ between the proportion of Protestants in each member state and those identifying only with their own nation-and not with Europe, while Catholic countries have higher levels of Europeanness [25]. Although it is rather difficult to trace the influence of the branch denomination on sense of Europeanness on individual level, Nelsen and Guth get similar results by comparing Christian denomination and attitude to the EU flag (EB 65.2). They found that "Catholics are more likely to identify with the flag and want it flown, while Protestants are much more resistant (46 v. $29 \%$ ). Eastern Orthodox Christians fall about in the middle of the spectrum, with just slightly less "flag identity" than the whole sample. In fact, this group is much less "European" than Catholics are, and they barely exceed Protestants" [25, p. 83]. They also noted that Catholics living in in majority Catholic countries have the strongest sense of "flag Europeanness", while those who live with Protestants in societies are less enthusiastic. They mainly proved this conclusion in their recent paper, using more complex method of analysis and new data [26].

But even a quick look at the data of recent EB (88-92) suggests that the interrelation between Christian denomination and European identity has much more complex and unstable nature. Distribution of the countries on the scale of EU citizens' feeling does not show any strong relevance to religion. EVS 2008 country data $^{22}$ do not indicate any strong correlation but gives us fairly interesting soft ties. Sense of belonging to Europe almost does not correspond to branch of Christianity. The only data that to appropriate extend may prove the idea that Catholic are more favourable to Europe is correlation between this denomination and identification as primarily European $(r=0,16)^{23}$. The proportion of Orthodox make the population of member-state less likely to belong first of all to Europe $(r=-0,2)$. But the coefficients are so small that it is impossible to see any stable tendency.

Catholic countries are regarded as more supportive for EU integration these means that on individual level people belonging to this religion should be more

\footnotetext{
${ }^{21}$ Denomination is not the only reason of this distance, but still it is a significant one.

${ }^{22}$ Calculation is based on valid percentage.

${ }^{23}$ Link between Protestantism and feeling primarily European is only $r=0,02$.
} 
confident in EU. Unfortunately, aggregated data of level of confidence in EU demonstrate also rather soft ties with religious denomination. The proportion of Catholics in each member state has almost insignificant connection with the confidence in EU ( $r=0,3)$. But we can prove the conclusion of Nelson and Guth, that the more Protestants live in the country the less convinced in EU the population is $(r=-0,5)$. The attitude of Orthodox differs from country to country: the highest percentage of confident people live in Romania (18\% of a great deal confident), while the lowest - in Latvia (6\%). The past of the member states, their economic situation can explain it better than the proportion of the Orthodox (that is true for the Protestant and Catholic countries).

Democracy is named as one of the main EU values that represent the institution. And we know that sociologist of religion concertedly claim that Protestant culture is more favourable for democracy. Indeed, the proportion of Protestant increase number of people who are strongly agree with the idea that democracy is the best political system $(r=0,28)$, while the proportion of Catholic reduce this number $(r=-0,3)$. But the aggregated data of the support to democracy show almost equal connection of Protestant and Catholic denomination and honour of democracy $(\mathrm{r}=\sim 0,2)$. Proportion of Orthodox may slightly decreases the support for democracy. Of course, the Soviet past and present political situation are more important factors of attitude to EU and democracy, but as we see denomination should not be neglected ${ }^{24}$.

Europe is mainly Christian, and the branches of Christianity formed different political cultures that are bound to influence the process of the European integration. We see the traces of it in particular position of the Protestant countries and even Brexit. On the individual level religious denomination also effect the sense of Europeanness, but as the native population of Europe is secular, they do not reflect any type of Christianity as a political or psychological basement of European identity. And this "believing without belonging" appears to be the platform of unification of Europeans, Christians as well as other denomination.

\section{Conclusion}

European identity is secular in its basis. Religion has no strong association with EU values or even with modern Europe. However, European identity is secular, not atheistic. Religion is present in its structure. This trivial idea finds appropriate, however fairly soft, evidence in the statistics data.

Which is more important religion being a factor of European identity not within that or this confession, but more as a faith. The role of Christianity is obvious in European heritage, but the minority religions, like Judaism or Islam, are not less important. Christian denominations influence attitude towards EU on national and somehow individual level, but none of it is a key factor of European identity. That is true to all confessions, even Christianity in general. While sense of religiousness, faith is likely to be more significant. Such as faith in democracy, human rights,

\footnotetext{
${ }^{24}$ Data of the 1-3 waves show almost the same interrelation between European identity and Christian branches.
} 
unity. Values of democracy, of the Enlightenment appear to be a secular religion of Europe and European Union.

Although it is crucial to remember that this religion does not individualize EU among the Western world. EU claims to be a citadel of democracy and human rights and it is definitely a part of European identity. But even EU citizens note that the institution needs more personalised face inside and outside. Probably the postsecular dialogue about the role of religions and churches in today democratic and civil practices could open a new door for the development of the European integration.

All the more EU is dealing with the world that is not secular. And in the optic of migration we have to admit that rigid secular attitude has not been working yet. Thus, considering European identity is seen as a construction, a type of formation discoursive, I suggest that approaching it within postsecular paradigm, considering presence of religion in public sphere, it is possible to strengthen it. The practical requirement of EU citizens equality regardless their worldview and the multiethnic democracy are crucial to the future of EU. And they are more likely to be reached on the postsecular basis.

\section{References}

[1] Norton A. On the Muslim Question. Princeton: Princeton University Press; 2013.

[2] Delanty G. The limits and possibilities of a European identity: a critique of cultural essentialism. Philosophy and Social Criticism. 1995; 21 (4): 15-36.

[3] Delanty G. Models of citizenship: Defining European identity. Citizenship Studies. 1997; 1: 3: 285-303.

[4] Nelsen B.F., Guth J.L., Fraser C.L. Does Religion Matter? Christianity and Public Support for the European Union. European Union Politics. 2001; 2 (2): 191-217.

[5] Pagdem A. (ed.) The Idea of Europe: From Antiquity to the European Union. Cambridge: Cambridge University Press; 2002.

[6] Walkenhorst H. The Conceptual Spectrum of European Identity. Missing Link to Unnecessary Evil. Limerick Papers in Politics and Public Administration. 2009; 3: 1-22.

[7] Foucault M. The Archeology of Knowledge. New York: Pantheon Books; 1972.

[8] Berger P.L. The Sacred Canopy. New York: Garden City: Doubleday; 1967.

[9] Habermas J. Religion and Rationality. Essays on Reason, God, and Modernity. Cornwall: Polity Press; 2002.

[10] Habermas J. Religion in the Public Sphere. European Journal of Philosophy. 2006; 14 (1): 1-25.

[11] Casanova J. Rethinking Secularization: A Global Comparative Perspective. The Hedgehog Review. Spring-Summer. 2006; 8 (1-2): 7-22.

[12] Asad T. Formation of the secular: Christianity, Islam, Modernity. Stanford: Stanford University Press; 2003.

[13] Uzlaner D. The end of religion? The history of the secularization theory. Moscow: HSE; 2019 (In Russ.).

[14] Uzlaner D. Postsecular turn. How to think about religion in XXI century? Moscow: Institute E. Gaidar; 2020 (In Russ.).

[15] Robinson W.S. Ecological Correlations and the Behavior of Individuals. American Sociological Review. 1950; 15 (3): 351-357.

[16] Willaume J.-P. La sécularisation: une exception européenne? Retour sur un concept et sa discussion en sociologie des religions. Revue française de sociologie. 2006; 4 (47): 755-783 (In French). 
[17] Casanova J. Religion, European secular identities, and European integration. In: Byrnes T.A. and Katzenstein P.J. (eds.). Religion in an Expanding Europe. Cambridge: Cambridge University Press; 2006. p. 65-92.

[18] Davie G. Is Europe an Exceptional Case. The Hedgehog Review. 2006; 8: 23-34.

[19] Davie G., Wilson E.K. Religion in European Society. In: Schewel B. and Wilson E.K. (eds.). Religion and European Society. A Primer. Hoboken: Wiley Blackwell; 2020. p. 15-31.

[20] Inglehart R. Cultural Evolution: People's Motivations are Changing, and Reshaping the World. Cambridge: Cambridge University Press; 2018.

[21] Harrison L.E. Jews, Confucians, and Protestants: Cultural Capital and the End of Multiculturalism. Plymouth: Rowman \& Littlefield Publisher, Inc; 2013.

[22] Huntington S.P. The Clash of Civilizations? Foreign Affairs. 1993; 7 (3): 29-30.

[23] Nelsen B.F., Guth J.L. Religion and the Struggle for European Union: Confessional Culture and the Limits of Integration. Washington: Georgetown University Press; 2015.

[24] Leustean L. The Ecumenical Movement and the Schuman Plan, 1950-54. Journal of Church and State. 2011; 53 (3): 442-471.

[25] Nelsen B.F., Guth J.L. Religion and the Creation of European Identity: The Message of the Flags. The Review of Faith \& International Affairs. 2016; 14 (1): 80-88.

[26] Nelsen B.F., Guth J.L. Losing Faith: Religion and Attitudes toward the European Union in Uncertain Times. Journal of Common Market Studies. 2020; 58 (4): 909-924.

\section{Information about the author:}

Galina S. Klimova - PhD in History, Associate Professor of the Department of International Politics and Foreign Regional Studies, Vice Dean of the School of Political Studies, the Institute for Social Sciences, The Russian Presidential Academy of National Economy and Public Administration (ORCID ID: 0000-0001-6847-1886) (e-mail: klimova-gs@ranepa.ru).

\section{Информация об авторе:}

Климова Галина Сергеевна - кандидат исторических наук, доцент кафедры международной политики и зарубежного регионоведения, зам. декана Школы политических исследований Института общественных наук Российской академии народного хозяйства и государственной службы при Президенте РФ (ORCID ID: 0000-0001-6847-1886) (e-mail: klimovags@ ranepa.ru). 